\title{
Novel Porous Ti-Based Alloys for Implants with Enhanced Bioactivity
}

\author{
Adriana Bernatiková ${ }^{1}$, Pavel Novák ${ }^{1}$, Dana Rohanová ${ }^{2}$ \\ ${ }^{1}$ University of Chemistry and Technology, Prague, Department of Metals and Corrosion Engineering, Technická 5, 166 \\ 28 Prague 6, Czech Republic, bernatia@vscht.cz \\ ${ }^{2}$ University of Chemistry and Technology, Prague, Department of Glass and Ceramics, Technická 5, 16628 Prague 6, \\ Czech Republic
}

Porous titanium implants are increasingly used for excellent corrosion resistance, mechanical properties similar to bone, biocompatibility and good osseointegration ability. The advantages of porous structure are lower density which causes better ingrowth of bone tissue. Changing the porosity influences resulting mechanical properties. Higher porosity decreases the elasticity modulus and tensile strength. Newly developed alloys based on titanium and silicon can be used as bone fillers, artificial interverbal discs, augmentations or dental implants. Titanium and silicon are nontoxic elements for human body, which is very important for biocompatibility. Another advantage of these alloys is that they have an ability to spontaneously create porous structures without pore forming agent. Pores support implant ingrowth. Varying the concentration of silicon influences the porosity of the alloys prepared by reactive sintering. The best mechanical properties were achived in the case of alloys with $2-7 \mathrm{wt}$. \% of silicon.

Keywords: Titanium implants, porous titanium, mechanical treatment, bioactivity.

\section{Acknowledgement}

This research was supported by the project TE01020390 financed by Technology Agency of the Czech Republic.

\section{References}

[1] CAO, W., HENCH, L.L. (1996). Bioactive materials. In: Ceramics International, Vol. 22, pp. 493-507. Elsevier

[2] WILLIAMS, D.F.(2008). On the mechanisms of biocompatibility. In: Biomaterials, Vol. 29, pp. 2941-2953. Elsevier. Belgium

[3] LEEUWENBURGH, S.C.G., et al. (2008). 20 - Calcium phosphate coatings A2 - Kokubo, Tadashi, In: Bioceramics and their Clinical Applications. , pp. 464-484. Woodhead Publishing.

[4] Available from: http://spinesolutionsfl.com/.

[5] RYAN, G., PANDIT, A., APATSIDIS, D.P. (2006). Fabrication methods of porous metals for use in orthopaedic applications. In: Biomaterials, Vo. 27, pp. 2651-2670. Elsevier.

[6] LONG, M., Rack, H.J. (1998). Titanium alloys in total joint replacement - a materials science perspective. In: Biomaterials, Vol. 19, pp. 1621-1639. Elsevier.

[7] XUE, W., LIU, X., ZHENG, X., DING, CH. (2005). Effect of hydroxyapatite coating crystallinity on dissolution and osseointegration in vivo. In: Journal of Biomedical Materials Research Part A, Vol. 74A, pp. 553-561. Caplus.

[8] BARBAS, A., BONNET, A.-S., LIPINSKI. P., PESCI, R., DUBOIS, G. (2012). Development and mechanical characterization of porous titanium bone substitutes. In: Journal of the Mechanical Behavior of Biomedical Materials, Vol. 9, pp. 34-44. Elsevier.

[9] NOVÁK, P., KŘÍŽ, J., MICHALCOVÁ, A., SALVETR, P. (2015). Role of Reactive Sintering in Production of Technically Important Intermetallics. In: Manufacturing Technology, Vol. 15, pp. 74-77. UJEP. Czech Republic.

[10] NOVÁK, P., MICHALCOVÁ, A. MAREK, I., VODĚROVÁ, M., VOJTĚCH, D. (2012). Possibilities of the observation of chemical reactions during the preparation of intermetallics by reactive sintering. In: Manufacturing Technology, pp. 197-201. UJEP. Czech Republic.

[11] de VIRETI, V.S.and .E.F., (2003). Titanium and Titanium Alloys as Biomaterials. In: Tribology - Fundamentals and Advancements, IK-Tekniker. Spain.

[12] PASSERI, G., CACCHIOLI, A., RAVANETTI, F., GALLI, C., ELEZI, E., MACALUSO, G.M. (2010). Adhesion pattern and growth of primary human osteoblastic cells on five commercially available titanium surfaces. In: Clinical oral implants research, Vol. 21(7), pp. 756-65. Medline

[13] LI, P.O.CH., KOKUBO, T., NAKANISHI, K., SOGA, N., DE GROOT, K. (1994). The role of hydrated silica, titania, and alumina in inducing apatite on implants. In: Journal of Biomedical Materials Research, Vol. 28, pp. 7-15. CAPLUS 
[14] KIM, H.M., MIYAJI, F., KOKUBO, T., NAKAMURA, T. (1996). Preparation of bioactive Ti and its alloys via simple chemical surface treatment. In: Journal of Biomedical Materials Research, Vol.32, pp. 409-417. CAPLUS

[15] KOKUBO, T., MIYAJI, F., KIM, H.-M., NAKAMURA, T., (1996). Spontaneous formation of bonelike apatite layer on chemically treated titanium metals. In: Journal of the American Ceramic Society, Vol. 79, pp. 1127-9. CAPLUS

\section{Paper number: M2016230}

Copyright $($ C 2016. Published by Manufacturing Technology. All rights reserved. 